$\mathrm{JMB}$

2,1

70

Received 24 August 2021

Revised 31 October 2021

Accepted 18 February 2022

\section{Impact of working capital
management on profitability: \\ Impact of working capital
management on profitability:
evidence from listed companies \\ Impact of working capital
management on profitability:
evidence from listed companies in Qatar}

\author{
Maad A. Q. Aldubhani, Jitian Wang and Tingting Gong \\ School of Economics and Management, Northeast Agricultural University, \\ Harbin, China, and \\ Ramzi Ali Maudhah \\ Faculty of Commerce and Economics, Al-Azhar University, Cairo, Egypt
}

\begin{abstract}
Purpose - This study aimed to find out whether working capital management policies affect the profitability of manufacturing companies listed on the Qatar Stock Exchange.

Design/methodology/approach - To assess the working capital management and profitability relationship, the authors applied a multiple regression analysis methodology in all manufacturing companies listed on the Qatar Stock Exchange (ten firms) between 2015 and 2019. Average collection period, inventory turnover, average payment period and cash conversion cycle were adopted as proxies for working capital management, and profitability was measured by operating profit margin (OPM), return on assets (ROA), return on capital employed (ROCE) and return on equity (ROE).

Findings - The study found that companies with shorter receivables collection periods and cash conversion cycles are more profitable. Longer inventory turnover periods and accounts payable payment periods are related to higher profitability of the firms.

Originality/value - Previous studies have assessed the relationship between working capital management and profitability. However, this study is the first one to use these four variables combined (OPM, ROA, ROCE and ROE) to measure profitability; this is what was limited in previous studies. In comparison, the previous studies were not comprehensive in studying the impact of working capital management on profitability from all aspects of profitability's variables [operational (OPM), economic (ROA), capitalist (ROCE) and financial (ROE)]. However, this study focused on all these aspects to make the results of the study more accurate. Also, it is worth mentioning that this study is the first research performed on Qatar Stock Exchange, although Qatar has achieved remarkable progress in the industrial sector in recent years, making it one of the first industrialized countries in the Middle East.
\end{abstract}

Keywords Qatar stock exchange, Manufacturing companies, Working capital management, Profitability Paper type Research paper

\section{Introduction}

Working capital management (WCM) is one of the challenges faced by companies, which can provide a convenient and appropriate level of liquidity for enabling companies to cover their short-term financial obligations - resulting from financing their operations - in order to ensure the continuity of the companies' business and maximize their profitability. WCM relates to current assets and current liabilities that represent an essential part of companies'

(C) Maad A. Q. Aldubhani, Jitian Wang, Tingting Gong and Ramzi Ali Maudhah. Published in Journal of Money and Business. Published by Emerald Publishing Limited. This article is published under the Creative Commons Attribution (CC BY 4.0) licence. Anyone may reproduce, distribute, translate and create derivative works of this article (for both commercial and non-commercial purposes), subject to full attribution to the original publication and authors. The full terms of this licence may be seen at http:// creativecommons.org/licences/by/4.0/legalcode
Journal of Money and Business Vol. 2 No. 1, 2022 pp. $70-81$

Emerald Publishing Limited e-ISSN: 2634-260X

p-ISSN: 2634-2596

DOI 10.1108/JMB-08-2021-0032 
total assets. Maintaining increased levels of current assets leads the company to achieve unprofitable profits on its total short-term investments. In contrast, relatively few current assets will make the firm vulnerable to difficulties and problems, perhaps rapid failure in managing the firm's operations, reducing the firm's capabilities to meet its short-term financial obligations, and increasing the firm's exposure to liquidity risk. Therefore, establishing a reasonable working capital policy will enable companies to increase profitability and create value for investors (Nguyen et al., 2020). Therefore, WCM plays a vital and influential role in the operational performance of the companies' owned resources, liquidity, profitability and thus on the company's value as a whole. Thus, companies strive to balance risks and returns resulting from investing in current assets to reach the optimum level of investment in working capital (Tsagem et al., 2015).

The importance of WCM also highlights the nature of the relationship between the method and cost of the financing assets, as current assets are usually financed from short-term sources of funds. The difference between current assets and current liabilities is the net working capital, which, if financed from long-term sources will increase the burdens and the costs incurred by the company, thereby negatively affecting its profitability (Subramanyam, 2014). In addition, the current situation caused by the COVID-19 pandemic points to the lack of liquidity and constrained credit similar to that occurred during and after the 2007 financial crisis. This made WCM a driving force behind the performance of industrial companies, where the companies must provide the necessary liquidity to finance their operations through automatic financing (WCM Effective Management) and short-term loans.

Hence, it can be said that working capital in the company is considered its lifeblood and one of the most critical factors that contribute to the continuity of the company's work, where the effective management of the working capital is a necessary process to achieve the company's goals.

Various studies have tackled the relationship between WCM and profitability. However, this study is the first one to use these four variables combined [operating profit margin (OPM), return on assets (ROA), return on capital employed (ROCE) and return on equity (ROE)] to measure profitability; this is what was limited in previous studies. In comparison, the previous studies were not comprehensive in studying the impact of WCM on profitability from all aspects of profitability's variables [operational (OPM), economic (ROA), capitalist (ROCE) and financial (ROE)]. However, this study focused on all these aspects to make the study results more accurate, which will provide companies with multiple criteria for evaluating working capital, provide more robust recommendations for WCM and enable companies to identify shortcomings in WCM that could affect their profitability (Osazevbaru et al., 2021). Also, no study has been performed before on Qatar Stock Exchange (QSE), although Qatar has achieved salient progress in the industrial sector in recent years, making it one of the first industrialized countries in the Middle East. Hence, this study aimed to investigate how the components of WCM (accounts receivable, inventory, accounts payable and cash conversion cycle) affect the profitability of listed manufacturing companies on the QSE measured by OPM, ROA, ROCE and ROE.

\section{Literature review}

WCM is one of the management concepts that focus on finding the optimum level of cash, inventory and debtors, also financing this level at the lowest possible cost through current liabilities to meet the company's daily needs (Brigham and Houston, 2009).

Companies have to know how to manage current assets and liabilities; there is a difference in managing each of its key elements, where appropriate management of each element affects the profitability of companies (Ehrhardt and Brigham, 2011). 
$\mathrm{JMB}$ 2,1

\subsection{Accounts receivable $(A R)$}

The accounts receivables management process begins with determining the company's credit policy. However, the company must have a system to monitor and control whether the credit conditions are applied and observed. Often there is a need to take corrective measures on some credit policies, and the only way to know if the situation is suitable and under control is to have a good receivables control system (Ehrhardt and Brigham, 2011). From an empirical perspective, Bieniasz and Gołaś (2011) and Enqvist et al. (2014) found a negative relationship between AR and firm's profitability, which indicates that the decrease in the number of days' collection from debtors will lead to a positive change in profitability.

Jakpar et al. (2017), Alvarez et al. (2021) and Amponsah-Kwatiah and Asiamah (2020) reported a positive relationship between AR and a firm's profitability.

Some authors have failed to find any significant relationship between AR and profitability (Arnaldi et al., 2021; Sensini et al., 2021).

\subsection{Inventory (INV)}

The inventory management process is one of the most critical issues of production management. The company management is responsible for providing the capital necessary to maintain the stock, where the lack of goods stock affects the sale process, which is the most important source of revenue for manufacturing companies, which may affect the profitability of these companies. The goal of inventory management is to ensure that there is a sufficient stock to ensure the continuity of the production process and to reduce the cost of holding stock to the lowest possible level (Brigham and Houston, 2009). Enow and Brijlal (2014) and Olaoye et al. (2019) pointed out that there is a positive relationship between INV and a firm's profitability where a high level of inventory prevents firms from losing sales (Jayarathne, 2014) and diminishes their risk of incurring the breakage costs in their production or supplying chain (Baños-Caballero et al., 2014; Deloof, 2003).

Some studies have shown a negative relationship between INV and a firm's profitability (Arnaldi et al., 2021; Aytac et al., 2020; Högerle et al., 2020).

\subsection{Accounts payable (AP)}

The accounts payable includes trade credit and accrued expenses, which together provide financing for business operations continuously (Bhattacharya, 2014). Previous studies have found a significant positive relationship between AP and profitability (Gonçalves et al., 2018; Hsieh et al., 2013; Mathuva, 2015). In turn, the companies can achieve more profits by taking a long time to pay creditors' bills for using this liquidity to finance investments in short-term assets (Jayarathne, 2014).

On the contrary, Deloof (2003) and Enqvist et al. (2014) identified a negative relationship between AP and profitability.

\subsection{Cash conversion cycle (CCC)}

Managing the cash conversion cycle is related to the period required to purchase and manufacture the raw materials and keep them in the form of stock, then sell the stock and collect the resulted cash or converting the debtors' bills to cash, all that depends on the nature of the work and the type of product (Brigham and Houston, 2009). Multiple studies have studied the relationship between WCM and profitability and have found a negative relationship between cash conversion cycle and profitability, indicating that a decrease in the corporate CCC will lead to a positive change in profitability (Arnaldi et al., 2021; Bieniasz and Gołaś, 2011; Enow and Brijlal, 2014; Enqvist et al., 2014; Muhammad Usman and Khan, 2017). 
Nevertheless, others found a positive relationship between CCC and profitability (Alvarez et al., 2021, Amponsah-Kwatiah and Asiamah, 2020).

In contrast to Jakpar et al. (2017), Rey-Ares et al. (2021) and Osazevbaru et al. (2021) there was no statistically significant relationship between the cash conversion cycle and the profitability.

Based on the objective of the study, the following null hypotheses were formulated and developed:

H1. There is no significant relationship between WCM represented by accounts receivable, inventory, accounts payable and cash conversion cycle on OPM in the listed manufacturing companies on QSE.

H2. There is no significant relationship between WCM represented by accounts receivable, inventory, accounts payable and cash conversion cycle on ROA in the listed manufacturing companies on QSE.

H3. There is no significant relationship between WCM represented by accounts receivable, inventory, accounts payable and cash conversion cycle on ROCE in the listed manufacturing companies on QSE.

H4. There is no significant relationship between WCM represented by accounts receivable, inventory, accounts payable and cash conversion cycle on ROE in the listed manufacturing companies on QSE.

\section{Methodology}

\subsection{Sample and data collection}

The study sample consisted of all the listed manufacturing companies on the QSE (ten manufacturing companies). The data were mainly collected from the published annual reports of listed manufacturing companies on the QSE during the period 2015-2019 taken from the Qatar e-Exchange website (Qatar Stock Exchange website, 2015-2019).

\subsection{Statistical analysis, models and variables}

This research conducted an empirical test of the impact of WCM on profitability by using the following:

Descriptive statistics were used to describe the minimum, maximum, mean and standard deviation values of the dependent (OPM, ROA, ROCE and ROE), independent (AR, INV, $\mathrm{AP}$ and $\mathrm{CCC}$ ) and control variables (ALog, SG and DR).

Pearson's correlation was used to explore the strength of the relationship between dependent, independent and control variables.

Variance inflation factor (VIF) was used to check the multicollinearity between the independent variables.

Multiple regression analysis was used to test the developed hypotheses; a linear regression analysis was performed to determine the essential component of working capital, which contributed more to forecasting the firm's profitability. Whereas the data looks like panel data, we are not interested in identifying (or comparing) the details of the companies among them in the manufacturing sector and the time factor. In fact, we are actually interested in the study variables in the manufacturing companies as a whole, so we will not use panel data analysis; we will use the multiple regression analysis methods. The regression equations are shown below. 
$\mathrm{JMB}$

2,1

Model 2:

$$
\begin{aligned}
\mathrm{ROA} \text { it }= & \beta 0+\beta 1(\mathrm{AR} \text { it })+\beta 2(\mathrm{INV} \text { it })+\beta 3(\mathrm{AP} \text { it })+\beta 4(\mathrm{CCC} \text { it })+\beta 5(\mathrm{ALog} \text { it }) \\
& +\beta 6(\mathrm{SG} \text { it })+\beta 7(\mathrm{DR} \text { it })+\varepsilon \text { it }
\end{aligned}
$$

Model 3:

$$
\begin{aligned}
\mathrm{ROEC} \text { it }= & \beta 0+\beta 1(\mathrm{AR} \text { it })+\beta 2(\mathrm{INV} \text { it })+\beta 3(\mathrm{AP} \text { it })+\beta 4(\mathrm{CCC} \text { it })+\beta 5(\mathrm{ALog} \text { it }) \\
& +\beta 6(\mathrm{SG} \text { it })+\beta 7(\mathrm{DR} \text { it })+\varepsilon \text { it }
\end{aligned}
$$

Model 4:

$$
\begin{aligned}
\mathrm{ROE} \text { it }= & \beta 0+\beta 1(\mathrm{AR} \text { it })+\beta 2(\mathrm{INV} \text { it })+\beta 3(\mathrm{AP} \text { it })+\beta 4(\mathrm{CCC} \text { it })+\beta 5(\mathrm{ALog} \text { it }) \\
& +\beta 6(\mathrm{SG} \text { it })+\beta 7(\mathrm{DR} \text { it })+\varepsilon \text { it }
\end{aligned}
$$

\begin{tabular}{|c|c|c|c|}
\hline Variable & $\begin{array}{l}\text { Variable } \\
\text { name }\end{array}$ & Calculation method & Reference \\
\hline \multirow[t]{4}{*}{$\begin{array}{l}\text { 1. Dependent } \\
\text { variable }\end{array}$} & OPM & Profit before interest and tax (PBIT)/Sales & $\begin{array}{l}\text { Khan and Choudhary } \\
(2020)\end{array}$ \\
\hline & ROA & EBIT/Total assets & Alvarez et al. (2021) \\
\hline & ROCE & EBIT/Capital employed & Al Dalayeen (2017) \\
\hline & ROE & Net profit/Total equity & Alvarez et al. (2021) \\
\hline \multirow[t]{4}{*}{$\begin{array}{l}\text { 2. Independent } \\
\text { variable }\end{array}$} & $\mathrm{AR}$ & $\begin{array}{l}\text { (Average of accounts receivable/Sales) } \times \\
365\end{array}$ & Jayarathne (2014) \\
\hline & INV & $\begin{array}{l}\text { (Average inventory/Cost of goods sold) } \times \\
365\end{array}$ & Jayarathne (2014) \\
\hline & $\mathrm{AP}$ & $\begin{array}{l}\text { (Average of accounts payable/Cost of goods } \\
\text { sold) } \times 365\end{array}$ & Jayarathne (2014) \\
\hline & $\mathrm{CCC}$ & $(\mathrm{AR}+\mathrm{INV}-\mathrm{AP})$ & Jayarathne (2014) \\
\hline \multirow[t]{3}{*}{ 3. Control variable } & ALog & $\begin{array}{l}\text { Natural logarithm of total assets }(\log A)=\ln \\
\text { (asset) }\end{array}$ & $\begin{array}{l}\text { Laghari and Chengang } \\
\text { (2019) }\end{array}$ \\
\hline & SG & $\begin{array}{l}\text { (Current year sales - Previous year sales)/ } \\
\text { Previous year sales }\end{array}$ & Jayarathne (2014) \\
\hline & $\mathrm{DR}$ & (Total liabilities/Total assets) & $\begin{array}{l}\text { Laghari and Chengang } \\
\text { (2019) }\end{array}$ \\
\hline
\end{tabular}

The study variables with measurements are illustrated in Table 1.

\section{Empirical result}

\subsection{Descriptive statistics}

The mean and standard deviation of OPM, ROA, ROCE and ROE were calculated. On average, the companies took 78 days to collect receivables, 112 days to convert inventory to

Table 1.

Study variables with measurement
Note(s): ALog, firm size; AP, number of days accounts payable; AR, number of days accounts receivable; CCC, cash conversion cycle; DR, debt ratio; INV, number of days inventory; OPM, operating profit margin; ROA, return on assets; ROCE, return on capital employed; ROE, return on equity; SG, sales growth 
sales and make payments in 50 days. CCC took 140 days to buy and turn the raw materials into stock, sell goods, collect the money from the customers and pay the money to creditors. Besides that, the average and standard deviation of ALog, SG and DR were illustrated in Table 2.

\subsection{Pearson correlation analysis}

Table 3 the correlation values for the independent and control variables range from -0.610 to 0.823, implying no multicollinearity because these values are below the 0.90 thresholds (Kasozi, 2017).

\subsection{Variance inflation factor (VIF)}

Referring to Table 4, the value of VIF was less than 10 for all the independent variables, which indicates the absence of multicollinearity between the independent variables and acceptance of the level of the variance in each independent variable for the study (Newbold et al., 2013).

\subsection{Multiple regression analysis}

For testing the developed hypotheses, a linear regression analysis was used to detect the most important component of working capital, which contributed more to the forecasting of the firm's profitability. The models' results were shown in Table 5.

4.4.1 Results of Model 1. Table 5 shows the multiple regression analysis of the independent variables related to WCM and the control variables on the OPM. The value of Adjust $R^{2}-$ which represents the ratio of the influence or interpretation of the independent variables on the variance of the dependent variable - was 0.615 . This means the independent variables of WCM and the control variables explained $61.5 \%$ of the variance in the OPM of listed manufacturing companies on QSE. Thus, the null hypothesis of the study was rejected. The alternative hypothesis was accepted, which states that there is a significant relationship between WCM represented by accounts receivable, inventory, accounts payable and cash conversion cycle on OPM in the listed manufacturing companies on QSE with F-sig (0.000). This result agreed with the works of Firmansyah et al., (2018), Khan and Choudhary (2020) and Mehtap (2016) and differed with the study of Panigrahi (2012). Moreover, Model 1 identified a statistically significant negative $(\phi<0.05)$ relationship between AR and OPM, which indicated that the decrease in the number of days' collected from debtors would lead to

\begin{tabular}{lccccc}
\hline Variables & Observations & Minimum & Maximum & Mean & Standard deviation \\
\hline OPM & 50 & 0.039 & 1.126 & 0.308 & 0.274 \\
ROA & 50 & 0.004 & 0.194 & 0.115 & 0.055 \\
ROCE & 50 & 0.061 & 0.353 & 0.173 & 0.064 \\
ROE & 50 & -0.028 & 0.204 & 0.09 & 0.054 \\
AR & 50 & 31.24 & 168.1 & 78.02 & 33.77 \\
INV & 50 & 26.24 & 343.8 & 112.6 & 72.2 \\
AP & 50 & 8.213 & 159.2 & 49.95 & 36.47 \\
CCC & 50 & 31.02 & 611 & 140.67 & 122.4 \\
ALog & 50 & 20.71 & 24.34 & 22.75 & 1.011 \\
SG & 50 & -0.645 & 1.202 & -0.006 & 0.293 \\
DR & 50 & 0.009 & 0.759 & 0.304 & 0.216
\end{tabular}

Note(s): ALog, firm size; AP, number of days accounts payable; AR, number of days accounts receivable; $C C C$, cash conversion cycle; DR, debt ratio; INV, number of days inventory; OPM, operating profit margin; ROA, return on assets; ROCE, return on capital employed; ROE, return on equity; SG, sales growth

Table 2.

Descriptive statistics variables 
$\underset{2,1}{\mathrm{JMB}}$

76

Table 3.

Pearson correlation analysis results

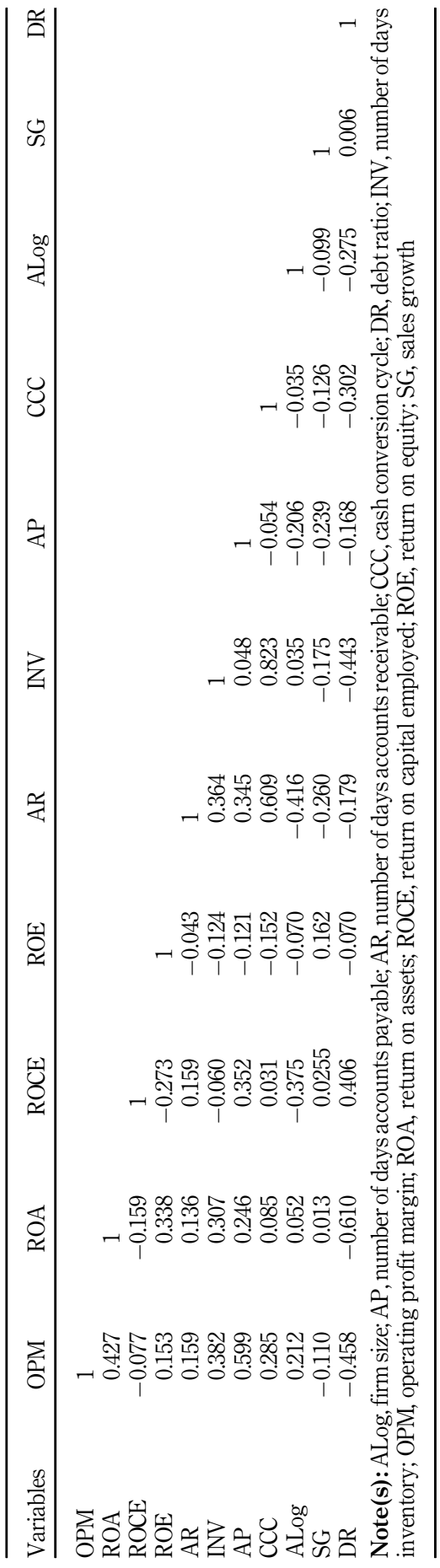




\begin{tabular}{lr}
\hline Variable & VIF \\
\hline AR & 3.85 \\
INV & 5.00 \\
AP & 1.54 \\
CCC & 7.22 \\
ALog & 1.80 \\
SG & 1.32 \\
DR & 1.64 \\
Mean VIF & 3.20
\end{tabular}

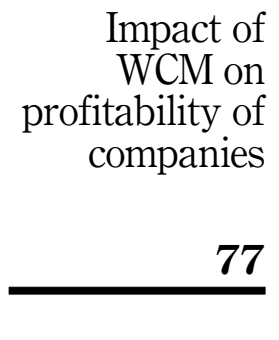

Note(s): ALog, firm size; AP, number of days accounts payable; AR, number of days accounts receivable; CCC, cash conversion cycle; DR, debt ratio; INV, number of days inventory; SG, sales growth; VIF, variance inflation factor

Table 4. VIF

\begin{tabular}{lccrr}
\hline Variables & $\begin{array}{c}\text { Model 1 } \\
\text { OPM }\end{array}$ & $\begin{array}{c}\text { Model 2 } \\
\text { ROA }\end{array}$ & $\begin{array}{c}\text { Model 3 } \\
\text { ROCE }\end{array}$ & \multicolumn{1}{c}{$\begin{array}{c}\text { Model } 4 \\
\text { ROE }\end{array}$} \\
\hline Intercept & $-1.244(0.220)$ & $0.614(0.543)$ & $1.553(0.128)$ & $0.769(0.446)$ \\
AR & $-0.373(0.038) * *$ & $0.271(0.225)$ & $-0.233(0.307)$ & $0.249(0.388)$ \\
INV & $-0.075(0.707)$ & $0.554(0.032) * *$ & $-0.171(0.510)$ & $0.121(0.711)$ \\
AP & $0.782(0.000) * * *$ & $0.026(0.855)$ & $0.529(0.001) * * *$ & $-0.252(0.169)$ \\
CCC & $-0.569(0.021) * *$ & $-0.679(0.029) * *$ & $0.491(0.120)$ & $-0.457(0.249)$ \\
ALog & $0.190(0.118)$ & $-0.006(0.970)$ & $-0.201(0.200)$ & $-0.075(0.704)$ \\
SG & $0.059(0.566)$ & $0.103(0.427)$ & $0.101(0.449)$ & $0.123(0.466)$ \\
DR & $-0.203(0.080)$ & $-0.519(0.001) * * *$ & $0.470(0.003) * * *$ & $-0.173(0.357)$ \\
$R^{2}$ & 0.670 & 0.473 & 0.444 & 0.112 \\
Adjust $R^{2}$ & 0.615 & 0.385 & 0.351 & -0.036 \\
F-statistic & 12.18 & 5.386 & 4.783 & 0.756 \\
F-sig & $0.000^{* * *}$ & $0.000^{* * *}$ & $0.001 * * *$ & 0.627
\end{tabular}

Note(s): *** and ** indicates significance at 1 and 5\% levels, respectively; ALog, firm size; AP, number of days accounts payable; AR, number of days accounts receivable; $\mathrm{CCC}$, cash conversion cycle; DR, debt ratio; $\mathrm{INV}$, number of days inventory; SG, sales growth

Table 5. Multiple regression results

a positive change in operating profit, where the decrease in AR is an indicator of the company's ability to collect money from customers and invest it in its operations, and thus the decrease in the company's need to finance its operations from external sources, which reduces the burden of external debt; and this is reflected positively on its ability to achieve operating profits this result consistent with the studies of Bieniasz and Gołaś (2011) and Enqvist et al. (2014) and contrary with the studies of Jakpar et al. (2017), Alvarez et al. (2021) and Amponsah-Kwatiah and Asiamah (2020). It also identified a statistically significant positive $(p<0.01)$ relationship between $\mathrm{AP}$ and $\mathrm{OPM}$, indicating that an increase in the corporate $\mathrm{AP}$ will lead to a positive change in operating profit, which means the companies withhold their payments to their creditors to take advantage of available cash for their working capital needs. Thus, the company can invest this additional money in short-term assets to increase profits. Nevertheless, it should be taken into account that a long repayment period may lead to the loss of good suppliers; therefore, the companies should maintain better relationships with their suppliers. This result is similar to the study of Gonçalves et al. (2018), Hsieh et al. (2013) and Mathuva (2015) findings and opposite to the studies of Deloof (2003), Enqvist et al. (2014) and Rey-Ares et al. (2021). The model found a statistically significant negative $(p<0.05)$ relationship between CCC and OPM; this means the company can enhance the 
operational profitability by reducing the $\mathrm{CCC}$, but this reduction must be in the limits of the optimum level because the continuous reduction below this limits will lead to a deficit in the net working capital which is necessary to support the operations and meet the demands of the companies. This result supported the findings of Arnaldi et al. (2021), Bieniasz and Gołaś (2011), Enow and Brijlal (2014), Enqvist et al. (2014) and Muhammad Usman and Khan (2017) and inconsistent with the findings of Alvarez et al. (2021), Amponsah-Kwatiah and Asiamah (2020) and Jakpar et al. (2017).

4.4.2 Results of Model 2. Table 5 displays that there is a significant effect between WCM and ROA, where the value of Adjust $R^{2}$ is 0.385 . Thus, the null hypothesis of the study is rejected, and the alternative hypothesis is accepted with $F$-sig $(0.000)$. This result is similar with the findings of Arnaldi et al. (2021), Nastiti et al. (2019), Singhania and Mehta (2017) and Vuković and Jakšic (2019) and conflicting with the study of Sarwat et al. (2017). Furthermore, Model 2 identifies a significant positive $(\phi<0.05)$ relationship between INV and ROA. The firms will be able to create value and increase performance and profitability by increasing the INV where the high inventory levels indicate the production capacity of the company to cover and meet the demands of the customers at any time, thus not losing the clients gradually by their going to other companies to purchase their needs due to the lack of required goods. It must be taken into account that the increase of INV must be within a reasonable and optimal level to avoid incurring storage and obsolescence costs for the companies. This result was agreed with the findings of Enow and Brijlal (2014) and Olaoye et al. (2019) and differed with the findings of Arnaldi et al. (2021), Aytac et al. (2020), Gonçalves et al. (2018) and Högerle et al. (2020). The model found a significant negative $(p<0.05)$ relationship between CCC and ROA and also $p<0.01$ between DR and ROA. These results are consistent with the findings of Arnaldi et al. (2021), Nguyen et al. (2020) and Pais and Gama (2015) and contrary with the findings of Chowdhury et al. (2018) and Cristian and Raisa (2017).

4.4.3 Results of Model 3. Empirical evidence in Table 5 shows the multiple regression analysis of the independent variables of WCM and the control variables on the ROCE. The value of Adjust $R^{2}$ is 0.351 . Thus, the null hypothesis of the study is rejected, and the alternative hypothesis is accepted with $F$-sig (0.001); this result supported the findings of Al Dalayeen (2017), Högerle et al. (2020) and Osazevbaru et al. (2021). Furthermore, this model identified a significant positive $(p<0.01)$ relationship between AP and ROCE and $p<0.01$ between DR and ROCE where the last result agreed with the findings of Chowdhury et al. (2018) and Cristian and Raisa (2017) and conflicted with the findings of Arnaldi et al. (2021), Nguyen et al. (2020) and Pais and Gama (2015).

4.4.4 Results of Model 4. Table 5 reveals that there is no significant effect between WCM and ROE. Where the value of Adjust $R^{2}$ was -0.036 , it was less than $20 \%$, which means the independent variables of WCM and the control variables could not explain the variance in the dependent variable (ROE). Where $F$-sig is 0.627 , it was more than $5 \%$, which indicated that the regression is not significant and not statistically acceptable. Thus, the null hypothesis of the study was accepted. This result is attributed to the clear disparity in the value of equity in Qatari companies, especially that some companies were distinguished by the presence of retained losses with clear values. Others were characterized by the high volume of reserves and retained earnings, which was reflected in the impact of working capital management on the ROE in companies. This finding is consistent with the findings of Rey-Ares et al. (2021) and differed with the findings of Alvarez et al. (2021), Amponsah-Kwatiah and Asiamah (2020), Gill et al. (2011) and Gorondutse et al. (2017).

\section{Conclusion}

This paper aimed to explore the impact of WCM policies on the profitability of industrial companies listed on the QSE. Data was collected from the annual reports of all manufacturing 
companies listed on the QSE (10 companies) during 2015-2019. Descriptive statistics, Pearson's correlation, VIF and multiple regression analysis were used to analyzing the data. The empirical results of the research showed that: (1) AR has a significant negative effect on OPM, which indicates that a shorter period of collecting money from customers will increase the profitability of companies; (2) INV has a significant positive effect on ROA, which means that higher inventory levels enhance corporates' profitability; (3) AP has a significant positive effect on OPM and ROCE, which implies that the companies can achieve more profits by taking a long time to pay creditors' bills, where the payment period to creditors topped the most significant impact on profitability among all WCM elements and (4) CCC has a significant negative effect on OPM and ROA, which denotes the company can enhance the profitability by reducing the cash conversion cycle.

The finding of the study also shows that WCM has no significant effect on ROE.

The managers must know how to manage working capital as it is essential to the profitability and performance of companies. The ideal management of working capital will provide the liquidity required to finance the company's operations through automatic financing (effective management of WCM components), which has become necessary under the lack of liquidity and credit constraints resulting from the COVID-19 crisis.

We also recommend conducting future studies linking spontaneous financing and its impact on the company's performance and profitability in various industrial sectors.

\section{References}

Al Dalayeen, B. (2017), "Working capital management and profitability of real estate industry in Jordan: an empirical study", Journal of Applied Finance and Banking, Vol. 7 No. 2, pp. 49-55.

Alvarez, T., Sensini, L. and Vazquez, M. (2021), "Working capital management and profitability: evidence from an emergent economy", International Journal of Advances in Management Economics, Vol. 10 No. 1, pp. 32-39.

Amponsah-Kwatiah, K. and Asiamah, M. (2020), "Working capital management and profitability of listed manufacturing firms in Ghana", International Journal of Productivity Performance Management, Vol. 21 No. 4, pp. 81-89.

Arnaldi, A., Novak, B., Roscigno, R. and Zhang, W. (2021), "Working capital management and profitability: empirical evidence", International Journal of Business Management and Economic Research, Vol. 12 No. 2, pp. 1911-1917.

Aytac, B., Hoang, T.H.V., Lahiani, A. and Michel, L. (2020), "Working capital management and profitability of wine firms in France: an empirical analysis", International Journal of Entrepreneurship Small Business, Vol. 41 No. 3, pp. 368-396.

Baños-Caballero, S., García-Teruel, P.J. and Martínez-Solano, P. (2014), "Working capital management, corporate performance, and financial constraints", Journal of Business Research, Vol. 67 No. 3, pp. 332-338.

Bhattacharya, H. (2014), Working Capital Management: Strategies and Techniques, PHI Learning Pvt.

Bieniasz, A. and Gołaś, Z. (2011), "The influence of working capital management on the food industry enterprises profitability", Contemporary Economics, Vol. 5 No. 4, pp. 68-81.

Brigham, E.F. and Houston, J.F. (2009), Fundamentals of Financial Management, Concise Edition, Cengage Learning.

Chowdhury, A.Y., Alam, M.Z., Sultana, S. and Hamid, M. (2018), "Impact of working capital management on profitability: a case study on pharmaceutical companies of Bangladesh", Journal of Economics, Business Management, Vol. 6 No. 1, pp. 27-35.

Cristian, M.M. and Raisa, M.L. (2017), "Working capital management and firm profitability", Empirical Evidence for the Romanian Industry, Ovidius University Annals, Economic Sciences Series, Vol. 17 No. 2, pp. 425-429. 
$\mathrm{JMB}$ 2,1

Deloof, M. (2003), "Does working capital management affect profitability of Belgian firms?", Journal of Business Finance Accounting, Vol. 30 Nos 3-4, pp. 573-588.

Ehrhardt, M.C. and Brigham, E.F. (2011), Financial Management: Theory and Practice-3rd, SouthWestern Cengage Learning.

Enow, S.T. and Brijlal, P. (2014), "The effect of working capital management on profitability: the case of Small Medium and Micro Enterprises in South Africa", The Journal of Accounting and Management, Vol. 4 No. 2, pp. 5-11.

Enqvist, J., Graham, M. and Nikkinen, J. (2014), “The impact of working capital management on firm profitability in different business cycles: evidence from Finland", Research in International Business and Finance, Vol. 32 No. 5, pp. 36-49.

Firmansyah, J., Siregar, H. and Syarifuddin, F. (2018), "Does working capital management affect the profitability of property and real estate firms in Indonesia?", Journal Keuangan Dan Perbankan, Vol. 22 No. 4, pp. 694-706.

Gill, A., Biger, N. and Mathur, N. (2011), "The effect of capital structure on profitability: evidence from the United States", International Journal of Management, Vol. 28 No. 4, p. 3.

Gonçalves, T., Gaio, C. and Robles, F. (2018), "The impact of Working Capital Management on firm profitability in different economic cycles: evidence from the United Kingdom", Economics Business Letters, Vol. 7 No. 2, pp. 70-75.

Gorondutse, A.H., Ali, R., Abubakar, A. and Naalah, M.N. (2017), "The effect of working capital management on SMEs profitability in Malaysia”, Polish Journal of Management Studies, Vol. 16 No. 5, pp. 89-97.

Högerle, B., Charifzadeh, M., Ferencz, M. and Kostin, K. (2020), "The development of working capital management and its impact on profitability and shareholder value: evidence from Germany", Strategic Management, Vol. 25 No. 2, pp. 27-39.

Hsieh, C. and Wu, C.Y. (2013), "Working capital management and profitability of publicly traded Chinese companies", The Asia Pacific Journal of Economics Business, Vol. 17 Nos 1/2, pp. 1-7.

Jakpar, S., Tinggi, M., Siang, T., Johari, A., Myint, K. and Sadique, M. (2017), "Working capital management and profitability: evidence from manufacturing sector in Malaysia”, Journal of Business \& Financial Affairs, Vol. 6 No. 2, pp. 1-9.

Jayarathne, T. (2014), "Impact of working capital management on profitability: evidence from listed companies in Sri Lanka", Proceedings of the 3rd International Conference on Management and Economics: Citeseer, pp. 269-274.

Kasozi, J. (2017), "The effect of working capital management on profitability: a case of listed manufacturing firms in South Africa”, Investment Management Financial Innovations, Vol. 14 No. 2, pp. 336-346.

Khan, A. and Choudhary, A. (2020), "Effect of working capital management on profitability of Bharti Airtel limited", Asian Journal of Management, Vol. 11 No. 1, pp. 92-96.

Laghari, F. and Chengang, Y. (2019), "Investment in working capital and financial constraints", International Journal of Managerial Finance, Vol. 4 No. 2, pp. 17-23.

Mathuva, D. (2015), "The Influence of working capital management components on corporate profitability", Journal of Business \& Financial, Vol. 4 No. 2, pp. 45-51.

Mehtap, Ö. (2016), "The impact of working capital management on firm profitability: empirical evidence from Borsa İstanbul”, Siyaset Ekonomi ve Yönetim Araştırmalar Dergisi, Vol. 4 No. 3 , pp. 63-79.

Muhammad Usman, S.A.S. and Khan, S. (2017), "Impact of working capital management on firm profitability: evidence from Scandinavian countries", Journal of Business, Vol. 11 No. 1, pp. 99-112.

Nastiti, P.K.Y., Atahau, A.D.R. and Supramono, S. (2019), "Working capital management and its influence on profitability and sustainable growth", Business: Theory Practice, Vol. 20 No. 4, pp. 61-68. 
Newbold, P., Carlson, W.L. and Thorne, B. (2013), Statistics for Business and Economics, Pearson, Boston, MA.

Nguyen, A.H., Pham, H.T. and Nguyen, H. (2020), "Impact of working capital management on firm's profitability: empirical evidence from Vietnam", The Journal of Asian Finance, Economics, and Business, Vol. 7 No. 3, pp. 115-125.

Olaoye, F., Adekanbi, J. and Oluwadare, O. (2019), "Working capital management and firms' profitability: evidence from quoted firms on the Nigerian stock exchange", Intelligent Information Management, Vol. 11 No. 3, pp. 43-60.

Osazevbaru, H.O., Aruoren, E.E. and Okunima, P. (2021), "Measuring the effect OF working capital management on firms' profitability: evidence from quoted Nigerian companies", International Journal of Management, Vol. 12 No. 3, pp. 133-142.

Pais, M.A. and Gama, P.M. (2015), "Working capital management and SMEs profitability: Portuguese evidence", International Journal of Managerial Finance, Vol. 8 No. 4, pp. 65-71.

Panigrahi, C. (2012), "Impact of working capital management on profitability-A case study of ACC Ltd”, Asian Journal of Management, Vol. 3 No. 4, pp. 27-33.

Qatar Stock Exchange website (2015-2019), “Annual reports of manufacturing companies”, available at: https://www.qe.com.qa/ar/financial-statements (accessed March 2021).

Rey-Ares, L., Fernández-López, S. and Rodeiro-Pazos, D. (2021), "Impact of working capital management on profitability for Spanish fish canning companies", Marine Policy, Vol. 130 No. 8, p. 104583.

Sarwat, S., Iqbal, D., Durrani, B.A., Shaikh, K.H. and Liaquat, F. (2017), "Impact of working capital management on the profitability of firms: case of Pakistan's cement sector", Journal of Advanced Management Science, Vol. 5 No. 3, pp. 33-39.

Sensini, L. and Vazquez, M. (2021), "Effects of working capital management on SME profitability: evidence from an emergent economy", International Journal of Business Management, Vol. 16 No. 4, pp. 85-95.

Singhania, M. and Mehta, P. (2017), "Working capital management and firms' profitability: evidence from emerging Asian countries", South Asian Journal of Business Studies, Vol. 6 No. 4, pp. 39-45.

Subramanyam, K. (2014), Financial Statement Analysis, McGraw Hill Education.

Tsagem, M.M., Aripin, N. and Ishak, R. (2015), "Impact of working capital management, ownership structure and board size on the profitability of small and medium-sized entities in Nigeria", International Journal of Economics and Financial, Vol. 5 No. 5, pp. 77-83.

Vuković, B. and Jakšić, D. (2019), "The effect of working capital management on profitability: evidence from southeast Europe”, Економцка пољопрцвреде, Vol. 66 №. 1, pp. 55-63.

\section{Corresponding author}

Jitian Wang can be contacted at: wangjitian2021@gmail.com

For instructions on how to order reprints of this article, please visit our website:

www.emeraldgrouppublishing.com/licensing/reprints.htm

Or contact us for further details: permissions@emeraldinsight.com 